\title{
A STUDY OF AUSTRALIAN TRADE CREDIT MANAGEMENT OUTSOURCING PRACTICES
}

\author{
DAWNE LAMMINMAKI \\ School of Accounting and Finance, Griffith University \\ and \\ CHRIS GUILDING \\ School of Accounting and Finance, Griffith University
}

\begin{abstract}
The results of a survey appraising the extent to which trade credit management (TCM) practices are outsourced by large Australian companies are reported. Of six distinct credit management functions appraised, it has been found that credit risk assessment is the most frequently outsourced activity. A cross-industry differential in TCM outsourcing is in evidence and it appears that sales orientated companies have a greater propensity to outsource TCM. Little support has been found, however, for the expectation that smaller companies have a greater propensity to outsource TCM.
\end{abstract}

JEL classification code: M30, M40.

Keywords: Outsourcing Trade Credit Management.

Correspondence to:

Associate Professor Chris Guilding

School of Accounting and Finance,

Griffith University

PMB 50

Gold Coast Mail Centre

Southport

QLD 9726

C.Guilding@griffith.edu.au

Tel: (07) 55528790

Fax: (07) 55528068

Acknowledgements: We thank Professor Richard Pike for insights provided during the survey development stage of this project. We also acknowledge the helpful comments made by two anonymous referees. 


\section{A Study of Australian Trade Credit Management Outsourcing Practices}

\section{Introduction}

There is a large theoretical and empirical corporate finance literature concerned with longterm financial instruments such as common and preferred shares, debentures and bonds. By comparison, minimal interest has been shown in developing organizational theory or conducting empirical research that is concerned with trade credit management (TCM), (Mian and Smith 1992, Pike and Cheng 1996). Yet trade credit constitutes a significant element of companies' liabilities and also assets (as accounts receivable). In their survey of small and medium sized UK firms, Wilson and Watson (1995) found that trade debtors comprise just under a third of corporate assets. With respect to the US., Mian and Smith (1994) note that for the 3,350 non-financial Nasdaq firms covered by COMPUSTAT, at the end of 1992, accounts payable represented $26 \%$ of corporate liabilities and accounts receivable represented $19 \%$ of corporate assets.

In light of the significant size accounts receivable can assume on the corporate balance sheet, during the recent trend of increased company downsizing and outsourcing, we might anticipate growing levels of interest in the possibilities of outsourcing TCM activities. ${ }^{1} \mathrm{~A}$ literature search has revealed, however, little research interest in TCM outsourcing. ${ }^{2}$ The study reported herein was conducted in light of the paucity of prior related research. The study's objectives are:

a) to appraise the incidence of TCM outsourcing in large Australian companies;

b) to develop and test propositions concerned with contingent factors that might affect TCM outsourcing. ${ }^{3}$

The paper is structured as follows. In the context of a review of what practices comprise TCM, the next section provides a synthesis of the most pertinent literature. This is followed by a section that develops a theoretical framework concerned with factors that might affect an organisation's propensity to outsource TCM. Subsequent sections address, in turn, the empirical research method employed, the empirical results and a conclusion that discusses the study's findings as

\footnotetext{
1 Roberts (1993) claims that outsourcing aspects of TCM is experiencing a resurgence in Australia.

2 Studies conducted by Mian and Smith (1994), Smith and Schnucker (1994), Sopranzetti (1998) and Summers and Wilson (2000), represent notable exceptions to this observation.

3 The empirical data reported herein represents a sub-set of data collected in a survey of Australian TCM practises. The survey was broadly concerned with determining the nature of Australian TCM practice.
} 
well as its limitations.

\section{What practices comprise trade credit management?}

Based on a priori reasoning, Mian and Smith (1992) break TCM into the following five underlying dimensions: 1) credit risk assessment, 2) the credit granting decision, 3) credit collection, 4) financing account receivables, and 5) the assumption of credit risk. This classification of TCM has been adopted as the underlying conceptual framework for appraising TCM outsourcing in the present study. Each of these dimensions of TCM are now discussed in turn in the context of outsourcing.

Credit risk assessment: Dun and Bradstreet Australia Pty. Ltd see credit risk assessment as concerned with "Keeping credit losses and slow collections of receivables from customers at a minimum, consistent with maintaining the company's volume at a level which will assure maximum income” (1995: 6). A widely used checklist for credit assessment has been the "3 Cs". These are: "character" (does the credit applicant have a predisposition towards timely repayment?), “capacity” (is the credit applicant capable of running a successful business?), “capital” (does the credit applicant have sufficient capital?) (Barbaro 1984, Scott 1981). More recently, this listing has been augmented by two further "Cs”, i.e., "conditions” (appraising the commercial environment of the credit applicant) and "collateral" (the ability to pledge assets as security). ${ }^{4}$

As credit risk assessment refers to the collection of data pertaining to the riskiness of extending credit to a particular customer at a particular point in time, outsourcing the function refers to the purchase of information (or an information collection service) pertaining to the riskiness of extending credit to a particular customer at a particular point in time. Mian and Smith (1992) suggest that the purchase of credit assessment information is more likely to occur when a new account is opened, a customer makes an uncharacteristically large purchase, or when a vendor believes the credit worthiness of a potential debtor has changed. This suggests that some companies may only outsource credit risk assessment for a subset of their sales ledger.

The credit granting decision: Credit risk assessment is a precursor to the credit granting decision. It is to be expected that responsibility for this decision will be frequently outsourced in

\footnotetext{
${ }^{4}$ See, for example, Pike et al (1997) and Society of Management Accountants of Canada (1990).
} 
non-recourse factoring arrangements. This is because a factor cannot be expected to assume exposure to the risk of a creditor defaulting without being able to determine when, and to whom, credit should be advanced. Besley and Osteryoung (1985) found US credit executives to be generally confident when deciding to grant credit. 84\% of their sample claimed they could adequately predict default and delinquency. Mian and Smith (1992) believe that outsourcing the credit granting decision function is less likely where a vendor's representatives regularly visit the purchaser's premises. In this type of situation, it is relatively efficient for the vendor to obtain information that can inform the credit granting decision (see Telser 1960). As will be noted below, however, the credit management function generally resides within the jurisdiction of the accounting function, not the marketing function. This mitigates the plausibility of Mian and Smith's view, as customer visitations will tend to be made by marketing personnel and not personnel representing the credit management function.

Credit collection: Advancements in electronic and communication technology are changing the way trade credit reimbursement is handled. In Pike et al's (1997) UK study it was found that cheque payments continue to be the most popular mode of reimbursement. They note, however, a growth in direct debit, electronic data interchange (EDI) and electronic funds transfer approaches. EDI can release significant benefits. In addition to reaping TCM cost savings, it can reduce the number of questions and errors arising in connection with ordering and invoicing activities. The significant initial investment required to install EDI systems may signify that they are not economically feasible for smaller companies, however. To realise the economies offered by such technology, smaller companies may have to outsource credit collection activities to credit collection specialists. The volume of activity conducted by such specialists allows them to make EDI investments and, due to competitive pressures in the industry, pass on economy of scale benefits to their clients.

Financing of accounts receivable: Accounts receivable can be financed in a passive manner out of general corporate resources, or, the vendor can borrow funds using account receivables as collateral. In Australia and Britain some of the large banks have factoring business units offering such lending services. In Australia these include the National Australia Bank, Westpac, as well as the Scottish Pacific subsidiary of the Bank of Scotland. In the US, the secured creditor is typically a commercial finance company or bank (Mian and Smith 1992).

The assumption of credit risk: Credit risk can be assigned to a third party by purchasing credit 
insurance. A variety of firms offer credit insurance with premiums, terms and conditions tailored to suit specific industry and company needs. Pike et al (1997) found 38\% of large UK firms purchased credit insurance, but only $17 \%$ took out insurance policies covering more than $70 \%$ of their credit turnover. Mian and Smith (1992) suggest that if the collateral in question is more valuable to the vendor than to the third party, then there may be a cost advantage in the vendor assuming the credit risk. This is because, if an account is not honoured, the vendor can repossess the merchandise and use their contacts and expertise in the industry to secure relatively favourable resale terms.

Credit collection of overdue accounts: Mian and Smith’s TCM typology has been augmented in this study by treating the collection of overdue accounts as a TCM activity warranting distinct consideration. This is because, for some companies, credit collection of overdue accounts might be the only aspect of TCM that is outsourced. TCM guidelines published by the Society of Management Accountants of Canada (1990) elaborate on the important role a collection agency can play with respect to overdue account management. ${ }^{5}$

\section{A contingency view of trade credit management outsourcing}

Perhaps the most fundamental corporate management decision to be made in connection with TCM concerns which activities can be performed more cost-effectively in house and which should be outsourced. The decision to outsource can be expected to be affected by a range of company specific factors. Propositions concerning three contingent factors that might affect trade credit management outsourcing decisions are developed in this section. These three factors are: company size, sales orientation and industry.

Size. Company size is expected to be negatively related to TCM outsourcing, i.e., larger firms are expected to outsource less. This expectation derives from the ability of larger firms to reap proportionately greater benefits from developing their own sophisticated trade credit management systems, as the fixed costs associated with developing and maintaining such systems can be spread over a greater number of customers and transactions. Smith and Schnucker (1994) comment on how debt factoring may provide more significant information processing savings when dealing with low-repeat business customers. Smaller companies can

\footnotetext{
5 Contact has been made with the Australian Institute of Credit Management, however it appears this body's training
} 
be expected to experience a greater incidence of low-repeat business. Also, as noted earlier, the growth of sophisticated modes of communication (e.g., EDI) may well signify an increase in fixed costs associated with credit collection. This development would appear consistent with increasing levels of TCM outsourcing by smaller companies, as it is only by concentrating TCM activities within trade credit specialist intermediaries that smaller companies may benefit from the economies offered by the new technology. Related to this notion, Mian and Smith (1992) found that relative to small companies, large companies have a greater propensity to develop specialised captive finance subsidiaries, thereby reaping scale economies.

In Bickers' (1994) UK study, it is claimed that increased outsourcing of TCM is related to small firms experiencing problems raising institutional finance and greater levels of bad debt in the smaller business sector. The problems experienced by smaller firms raising debt are also commented on by Ennew and Binks (1996) and Storey (1994). As Summers and Wilson (2000) note in their UK study, if a small firm experiences problems raising finance, selling accounts receivable can help in two ways: cash associated with a sale is received earlier and finance can be raised if a firm has insufficient or inappropriate fixed assets to pledge as collateral in a conventional loan arrangement.

These views are also consistent with the transaction cost economics theorem (Coase 1937, Williamson 1975, 1985). Transaction cost economics comprises a theoretical framework concerned with what activities will be managed within the firm ("mediated hierarchically"), and which activities will be outsourced ("mediated by the market”). According to this theory, three activity attributes (referred to as transaction attributes), moderate a company’s propensity to outsource the activity. These three attributes are: asset specificity, uncertainty and frequency. Proponents of transaction cost economics hold that increasing levels of any or all of these three attributes increases the likelihood of the activity in question being mediated hierarchically. Of pertinence here is the frequency attribute, which Colbert and Spicer (1995) refer to as “extent” in order to capture both the frequency and volume with which an activity is conducted over time. Due to their size, larger firms can be expected to have a greater "extent” of TCM activities taking place. Testing the following proposition thus represents a partial test of the transaction cost economics framework in the relatively novel context of TCM.

Proposition 1: Degree of trade credit management outsourcing is negatively related to company 
size.

Sales orientation. There is a fairly well-defined vein of accounting commentary that highlights the problematical nature of the sales and accounting functional interface (Ratnatunga et al 1989, Simmonds 1986, Wilson 1986). The schism that characterises this interface is particularly apparent from the enduring nature of Berry’s observation made more than 20 years ago:

"Given: one marketing manager and one accounting manager. Finding: poor communication on financial criteria and goals” (1977: 125).

Because of the contrasting and frequently conflicting orientations of the accounting and selling functions, a high corporate sales orientation is suggestive of a low accounting orientation.

TCM would appear to represent an organisational activity with significant scope for manifesting conflict between the accounting and sales functions. This is because it is located at the nexus of the accounting and sales functions. Sales promotion and customer management underlines a sales manager's interest in TCM, yet the monitoring and management of receivables tends to be organised as an activity within the accounting/finance function (Kirkman 1977). The apparent scope for a sales orientation impacting on TCM highlights the potential of it also being implicated in the TCM outsourcing decision.

In their Australian case study investigation of credit risk assessment, Hutton et al (1997) found that credit managers did not feel comfortable using credit as a sales promotion device. They were either negative or ambivalent towards the sales department and did not see credit as relevant to sales promotion. The objective espoused by credit control managers was bad debt minimisation. They attached little importance to the volume of profits or sales associated with accounts. One credit control manager interviewed commented "sales are the biggest enemy of credit" (Hutton et al, 1997: 13). This observation highlights the considerable potential for a rift between credit and sales personnel when TCM is organised as part of the accounting/finance function. Edwards (1990) notes that when TCM resides within the marketing/sales ambit of the organization, it can assume a sales and customer-orientation, with less significance attached to default risk. When associated with the accounting function, however, TCM will be used less as a selling vehicle and concerns over the minimisation of exposure and bad debts will tend to predominate the objectives of the function. ${ }^{6}$

\footnotetext{
${ }^{6}$ Because of the contrasting orientations of the accounting and marketing functions, Bass (1991) suggests treating TCM as an independent unit reporting to the finance director.
} 
In companies with a heightened sales orientation, managers are confronted by the problem of reconciling this orientation with TCM falling under accounting governance. It is to be expected that a company exhibiting a high sales orientation and a low accounting orientation would attach relatively low importance to the development of in-house financial expertise concerned with credit management. One way of managing this problem might be to outsource the TCM function. This view appears to be supported by the TCM guidelines developed by the Society of Management Accountants of Canada (1990) which suggest outsourcing TCM can lessen the scope for TCM policy conflict between sales and finance departments. Related to this issue, Pike et al (1997) suggest that outsourcing TCM is particularly appropriate in marketing orientated firms as there may be a tendency for such firms to pay insufficient attention to accounts receivable management.

An additional reason for an expectation that a strong corporate sales orientation is consistent with greater TCM outsourcing is apparent from Slater and Narver's (1994) discussion of marketing orientation. Slater and Narver consider marketing orientation from two perspectives. With respect to the first perspective, they see a marketing orientation as apparent in firms that employ a multi-functionalist structure designed to focus on the pursuit of maximising customer value as well as the avoidance of shortcomings apparent in traditional functional structures. This perspective highlights a greater propensity to move TCM outside the accounting/finance sphere of influence in marketing orientated companies. With respect to the second perspective, Slater and Narver believe a marketing orientation to be apparent in companies that emphasize obtaining information about customers, competitors and markets. Active solicitation of information about customers appears to be consistent with a greater propensity to outsource TCM activities (especially credit risk assessment and the credit granting decision), and provides further grounds for the expectation that companies with a high sales orientation have a greater propensity to outsource TCM activities.

Proposition 2: Companies with a high sales orientation have a greater propensity to outsource trade credit management activities.

Industry. Mian and Smith (1992) discuss several factors that might lead to differential rates of TCM outsourcing across industries. For example, they see a greater role for TCM outsourcing in industries with many vendors selling to many purchasers. In an industry characterised by a 
relatively high number of buyers and sellers there is greater potential to release economies of scale by centralising the industry's credit monitoring within a single intermediary. Mian and Smith anticipate an amplification of scale economies in industries experiencing seasonality, however their empirical study failed to find any relationship between seasonality and TCM outsourcing in the US. Further, in industries where significant investment is required to secure purchaser specific credit information, a credit specialist intermediary is exposed to the potential of post-contractual opportunistic behaviour (Klein et al, 1978). This notion relates to the transaction cost economics theorem discussed earlier. Asset specificity, which concerns the extent to which an asset's value depends on its continued use in the trading relationship for which it was developed, can be seen to be present in industries that have a limited number of vendors and relatively distinct trading relationships. If, as part of a service to a particular client, a trade credit intermediary were to invest resources collecting credit information concerning a particular supplier in a narrow based industry, it would need to price its service at a rate that recognises the low likelihood of the information collected being of value to any of its other clients, i.e., the asset value of the information collected is highly dependent on the company that requested the information continuing to purchase the credit intermediary's service. It follows that in industries with a few vendors and relatively distinct trading relationships, TCM outsourcing will be constrained.

A further cross-industry factor that might contribute to differing levels of TCM outsourcing is the incidence of international trade. In those industries with a relatively high incidence of international trade, greater problems related to assessing credit worthiness and also collecting overdue accounts are to be expected. This is because the international dimension introduces language, cultural and time zone differences. Further, Summers and Wilson (2000) note that in the UK, TCM outsourcing has tended to be associated with certain sectors such as the textile industry. They conclude that the offering of TCM outsourcing services by speciality firms may well be more developed in some industries relative to others. This reasoning suggests that several industry specific factors might cause a cross-industry variance in the incidence of TCM outsourcing. This expecation motivates proposition 3.

Proposition 3: There is significant cross-industry variation in the extent to which trade credit management activities are outsourced.

\section{Empirical tests}




\subsection{Sampling procedure}

Data has been collected via a mailed questionnaire survey. ${ }^{7}$ The initial sample comprised the top 300 Australian listed companies (measured by market capitalisation), obtained from the "Shareholder” CD-Rom database. Of this initial sample, 45 companies were dropped as they belong to industries where minimal credit sales are expected (e.g., financial services, retail, hotels, sister companies, etc.). This procedure resulted in a sample frame comprising 255 companies. Of this revised sample, 9 company addresses were found to be incorrect, and 6 companies advised that participation in the study would contravene company policy. The final adjusted sample size is 240 companies.

The questionnaire, together with a covering letter and a return self-addressed envelope was mailed to the Chief Accountant of each company. A second mail-out to all non-respondents was undertaken two weeks following the initial mailing. Responses were received from 85 Chief Accountants, representing a response rate of 35\%.

Three investigations for non-response bias were undertaken. Firstly, ten non-respondents were randomly selected and encouraged to participate in the study when contacted by telephone. Six managers advised that they had not participated due to time constraints, and four managers advised that participation contravened company policy. No comments giving rise to a concern for non-response bias were noted. The second approach involved applying the Mann Whitney $U^{8}$ statistic in an investigation for differences in TCM outsourcing information provided by early and late respondents (Armstrong and Overton 1977). No statistically significant differences across these two sub-samples were noted. The final test for non-response bias involved a $t$-test analysis of differences in market capitalisation and total assets of the sample data with the population data. No statistically significant differences were noted. $^{9}$

\footnotetext{
7 The survey instrument was based on the Pike and Cheng (1996) questionnaire which was extensively piloted in the UK. This survey was administered in 1999.

8 The Mann Whitney $U$ statistic is based on the number of times a score from one sample ranks higher than a score from a second sample (Tabachnick and Fidell 2001).

9 The $t$-test statistic was used because market capitalisation and total assets qualify as continuous, interval measures. In all statistical analyses involving the outsourcing of TCM, which was measured using Likert-scales, non-parametric statistical analyses have been used.
} 


\subsection{Variable measurement}

Degree of TCM outsourcing. Following the question, "To what extent do you involve a factor (or other organizations specialising in trade credit management) in the following activities?", the six TCM activities described above were listed. Next to the reference to each TCM activity, a Likert scale ranging from "1" (labelled “not at all”), to "5" (labelled “very frequently”) was provided.

Size. Two measures of company size have been employed: market capitalisation and book value of assets. Both these measures were obtained from the "Shareholder" data base. The companies comprising the data set had market capitalisations ranging from $\$ 9.5 \mathrm{~m}$ to $\$ 4,130 \mathrm{~m}$ and assets ranging from $\$ 10.2 \mathrm{~m}$ to $\$ 9,222 \mathrm{~m}$.

Sales orientation. The most pertinent aspect of sales orientation in this study relates to its manifestation in TCM. An example of how TCM policy can reflect a sales orientation is apparent in Miller's (1996) suggestion of relaxing credit risk criteria in order to promote sales of stock which are slow-moving, obsolete or seasonal. Other ways in which TCM can be used in a manner supportive of selling initiatives include adjusting credit terms to secure large orders, win new customers or retain existing customers. ${ }^{10}$ Four proxies for a sales orientation in TCM were measured by asking respondents to indicate whether they modify standard credit terms in connection with each of the following selling objectives:

- to gain large orders from existing customers.

- to win new customers.

- to keep existing customers

- to promote slow moving/declining products.

Industry. Each respondent's company was identified with one of the 16 industries referred to in the "Shareholder" database (1996) industrial classification. For the purposes of statistical analysis this classification has been collapsed into five industrial categories: Extractive (24 companies), Manufacturing (15 companies), Construction (12 companies), Electronic and telecommunications (10 companies) and miscellaneous (24 companies).

\section{Results}

10 This final initiative can be expected to be of growing significance, given the rise of the "relationship marketing” business 
Table 1 presents descriptive statistics concerning the extent to which each of the six TCM practices are outsourced. The practices are presented in descending order of degree of outsourcing, with means ranging from 2.49 (credit risk assessment) to 1.27 (financing of accounts receivable). For each practice appraised, actual scores ranged across the full theoretical range. Using the Wilcoxon matched pairs test, ${ }^{11}$ each practice was found to be outsourced statistically significantly more than the next highest ranking practice.

Insert Table 1 about here

Table 2 presents correlation statistics for the six factoring practices. The statistically significant positive correlations for all combinations signify that a company outsourcing one aspect of TCM to a relatively high degree was likely also to outsource other aspects of TCM to a relatively high degree. Only two combinations of variables fail to yield statistically significant correlations at the 0.01 level of confidence, i.e., only a 0.05 confidence limit applies to the statistically significant relationships between credit insurance outsourcing and credit risk assessment outsourcing and credit collection outsourcing.

Insert Table 2 about here

An exploratory factor analysis was conducted in order to investigate further for any underlying pattern in the outsourcing rates of the six TCM practices. ${ }^{12}$ The principal components method of extraction with varimax rotation was used. This analysis yielded two factors with eigenvalues greater than 1 (see Table 3). Four of the six TCM practices loaded most heavily on the first factor (ie., the outsourcing of credit collection, credit granting decisions, credit risk assessment, and credit collection of overdue accounts) and two items loaded most heavily on the second factor (ie., outsourcing of credit insurance and the financing of accounts receivable). The suggestion revealed in the correlation analysis that outsourcing credit insurance might be less congruent with outsourcing levels of the other TCM practices is provided further support by the factor

\footnotetext{
philosophy.

${ }^{11}$ The Wilcoxon matched pairs test ranks the size of differences between two related measures and sums those with the same sign (Tabachnick and Fidell 2001).

12 Factor analysis is a statistical technique used to determine which variables form coherent subsets that are relatively independent of one another (Tabachnick and Fidell 2001). A cautionary note is warranted when interpreting the results of the factor analysisconducted here. The limited variability apparent in the degree to which the six TCM practices are outsourced (see Table 1) is bound to detract from the reliability we can attach to the factor analytic findings.
} 
analysis. Of the six practices appraised, credit insurance loads least heavily on the dominant factor yielded by the principal components analysis and most heavily on the second factor. When attempting to interpret the two factor result of the principal components analysis, it appears that the practices loading most heavily on the main factor relate to the more routine activities undertaken in a trade credit management department. The two items loading most heavily on the second factor appear to represent more ad hoc and less routine aspects of trade credit management. A second distinguishing feature might be that credit insurance and financing of accounts receivable are used more in connection with international trade where accounts can be outstanding for a longer period of time and the vendor may feel exposed to a greater degree of risk. It is notable that these two items represented the dimensions of TCM outsourcing that exhibited the lowest mean scores in Table 1.

Insert Table 3 about here

Recall that proposition 1 posited a negative relationship between degree of TCM outsourcing and company size. This proposition has been tested by correlating outsourcing rates of the six TCM practices with two measures of company size: market capitalisation and book value of assets. The results of the correlation analysis are presented in Table 4. Outsourcing three aspects of TCM (credit collection of overdue accounts, credit insurance and financing of accounts receivable) have been found to be statistically significantly negatively associated with market capitalisation. Although a negative relationship has been observed for outsourcing five of the six TCM practices and total assets, none of these relationships is statistically significant. We can thus conclude that of the twelve relationships examined, eleven are directionally consistent with the proposition that size is negatively related to TCM outsourcing, however only three relationships are statistically significant. A degree of caution is warranted when interpreting these three significant findings as two of them relate to TCM practices that are outsourced the least. This concern is somewhat mitigated, however, by the fact that non-parametric statistics have been used throughout this study's proposition testing. ${ }^{13}$ No convincing rationale why TCM outsourcing would be more strongly related to market capitalisation than company assets has been developed. Overall, these findings should not be viewed as providing significant support for proposition one, although they would appear to offer sufficient support to warrant further enquiry into the relationship between size 13 Non-parametric statistics do not require precise assumptions about the nature of the distribution of the sampled
population. 
and TCM outsourcing. At the very least, it would appear appropriate to appraise size in any further examinations of factors affecting TCM outsourcing.

\section{Insert Table 4 about here}

Proposition 2 posits a positive relationship between a company's sales orientation and its propensity to outsource TCM activities. This proposition has been tested by investigating for relationships between outsourcing the six TCM and the four dimensions of sales orientation described in the previous section. Table 5 presents the mean TCM outsourcing scores according to companies that either do, or do not, modify credit terms in connection with each of the four selling objectives. For each dimension of sales orientation appraised, the Mann Whitney $U$ statistic has been used to compare TCM outsourcing levels across the four dichotomised groupings of sales orientation. It has been found that for companies that modify credit terms to win new customers, only one aspect of TCM is outsourced statistically significantly more (credit collection of overdue accounts, $p<0.1$ ). For companies that modify credit terms to gain large orders from existing customers, four aspects of TCM are outsourced more (credit risk assessment, $p<0.05$; credit collection, $p<0.05$; collection of overdue accounts, $p<0.05$; and credit insurance, $p<0.05)$. For companies that modify credit terms in order to promote slow moving/declining products, there is greater outsourcing of credit risk assessment $(p<0.1)$, credit granting decision making ( $p<0.1$ ), collection of overdue accounts $(p<0.01)$ and credit insurance $(p<0.05)$. Adjusting credit terms to keep existing customers has not been found to be statistically significantly related to outsourcing of any of the TCM practices appraised. Considered holistically, these findings represent some, albeit not strong, support for proposition 2.

Insert Table 5 about here

The Kruskal Wallis $H$ statistic $^{14}$ (analysis of variance) has been used to test proposition 3 which concerns the existence of a differential in cross-industry rates of TCM outsourcing. The crossindustry mean scores for TCM outsourcing, together with the results of applying the analysis of variance test are presented in Table $6 .{ }^{15}$ From this table, it can be seen that for four TCM

\footnotetext{
14 The Kruskal Wallis $H$ statistic is similar to the Mann Whitney $U$ statistic, except it can be used to compare scores across more than two sub-groups (Tabachnick and Fidell 2001).

15 The miscellaneous industry category has not been included in this Table nor the analysis of variance test conducted.
} 
practices the differential in cross-industry outsourcing rates is statistically significant (credit risk assessment, $p<.05$; credit collection, $p<.05$; collection of overdue accounts, $p<.05$; and financing of accounts receivable, $p<.1$ ). These findings provide fairly strong support for proposition 3.

Insert Table 6 about here

\section{Summary and conclusions}

The contribution of this study is apparent when we recognise the dearth of prior research concerned with trade credit management, and trade credit management outsourcing in particular. A literature review has revealed only a handful of related studies (Mian and Smith 1994, Smith and Schnucker 1994, Sopranzetti 1998, and Summers and Wilson 2000), and no recently published academic study concerning Australian trade credit management practices has been found. ${ }^{16}$

Three main findings can be distilled from the study. First, use of TCM outsourcing in Australia is somewhat limited. A mean score below the mid-point of the "used not at all / used very frequently” Likert scale has been reported for outsourcing levels of all the practices appraised. The possibility that these scores are somewhat understated, however, should be noted. The survey instrument used for data collection also addressed other TCM issues. Most of these issues lie beyond the scope of this paper. Companies that extensively outsource their TCM functions may have declined to complete and return the questionnaire as the accountant may have felt that the operational TCM issues addressed in the questionnaire were of limited relevance, given their decision to outsource the function. The data collected may thus be biased in a way that understates average TCM outsourcing rates in large Australian companies. While this potential limitation should be highlighted, we should also note that tests for non-response bias have failed to expose any systematic response biases.

The second main finding relates to the differential degrees to which each of the six TCM functions are outsourced. It has been found that credit risk assessment is the most frequently outsourced TCM practice. This finding is not surprising given the ad hoc nature with which

\footnotetext{
16 In the course of this paper's review process, it was brought to the authors' attention that Dr Barry Hutton recently completed an RMIT University PhD thesis concerned with credit risk assessment in Australia.
} 
this type of outsourcing can be conducted. For a relatively small fee a company can seek credit assessment information on a single potential trade creditor. The decision to seek such credit advice can be considered relatively insignificant in comparison to the decision to outsource the other TCM activities considered in the study.

The third main finding relates to the study's contingency design. Only a modicum of evidence supportive of the view that smaller firms have a greater propensity to outsource TCM has been provided. Stronger evidence supportive of the view that there is a crossindustry differential in TCM outsourcing rates and also that companies with a high sales orientation have a greater propensity to outsource TCM has been uncovered.

The weak nature of the support given to the view that smaller firms outsource TCM more should be considered in the context of Summers and Wilson's (2000) UK observation that both credit sales and assets are negatively correlated to factoring. It is difficult to propose a strong rationale why there should be an international difference in the company size / propensity to outsource relationship. Perhaps the factoring industry is less developed in Australia and, relative to their UK counterparts, maybe smaller Australian companies experience greater difficulty securing the services of companies willing to offer TCM outsourcing services. Consistent with the rationale developed earlier, the strength of the company size effect may well become amplified in the future as continuing technological developments create a greater cost saving for those companies able to justify the investment in such technology. It is only by outsourcing to TCM specialists that smaller companies will be able to realise such cost savings. Accordingly, there would appear to be appropriate motivation for future investigations of the context of TCM outsourcing that consider the company size variable.

The finding that companies with a high sales orientation have a greater propensity to outsource TCM is believed to be highly illuminating. The rationale provided here for this finding is that firms with a high sales orientation have a greater propensity to outsource their trade credit management activities in order to minimise the potential for internal tension and management conflict. By moving the TCM function outside the remit of the accounting function it may well be that sales managers are given greater scope to incorporate sales promotion objectives in the way the trade credit extension decision is approached. It should be noted that support for this finding is also evident in Summers and Wilson's (2000) UK 
study that reports a positive relationship between factoring and a company's propensity to modify credit terms for a variety of marketing related reasons.

With respect to the industry aspect of the study's contingency design, it has been found that companies in the extraction and exploration industries have the lowest propensity to outsource TCM practices. Relative to companies in other industries, companies in this industry can be expected to have few trading relationships. This finding appears consistent with the "asset specificity" rationale outlined earlier, and therefore can be seen to be supportive of the transaction cost economics theoretical framework. In addition, as the output of these industries tends to be intermediate and not finished goods, it would be more difficult for an independent party without industry specialist knowledge and contacts to recoup the value of a debt, should it be necessary to repossess goods following a default on a trade account payable.

In addition to the normal shortcomings associated with survey research, this study suffers from the following limitations:

1. The potential of the survey data collected being overly representative of firms that do not outsource their TCM function has already been highlighted. If a higher response rate had been achieved, greater confidence could be attached to the findings reported. Despite this, any potential for the degree of TCM outsourcing being understated is unlikely to subvert interpretation of the ranking of the outsourcing rates of TCM practices, or the proposition testing. This is because any understatement of TCM outsourcing is likely to be constant across the six practices considered and unrelated to the three independent variables invoked in the proposition testing.

2. Although empirical support for the proposition concerned with sales orientation has been provided, it is believed the study would have been strengthened had the sales orientation measures been constructed using Likert-style measures rather than the dichotomous measures that have been employed. As it is to be expected that companies may exhibit degrees of sales orientation, a measure capturing relativity is recommended in future work designed to capture the sales orientation construct. Further, in any research designed as a partial replication of this study, consideration could be given to measuring sales orientation at the corporate level rather than the TCM functional level, which was the approach taken in this study. 
A potentially fruitful research initiative that builds on this study could involve collecting data from specialist financial institutions that offer trade credit management services (eg., companies such as Dun \& Bradstreet and the banks). Interview data could be collected to further investigate what are the main aspects of TCM that are outsourced, whether certain characteristics predispose a company to high rates of TCM outsourcing and to further our understanding of the particular contingencies that can lead to a company considering TCM outsourcing. 


\section{REFERENCES}

Armstrong, J.S., and T.S. Overton, 1977, “Estimating nonresponse bias in mail surveys”, Journal of Marketing Research, 14: 396-402.

Barbaro, F., 1984, Commonsense Credit Control and Management, Rydges Publications Pty. Ltd, Sydney.

Bass, R.M.V., 1991, Credit Management: How to manage effectively and make a real contribution to profits, $3^{\text {rd }}$ edition, Stanley Thornes Ltd, London.

Berry, D., 1977, "Profit Contribution: Accounting and Marketing Interface”, Industrial Marketing Management, 6, 2: 125-128.

Besley, S., and J.S. Osteryoung, 1985, "Survey of Current Practice in Establishing Trade-credit Limits”, The Financial Review, February: 70-82.

Bickers, M., 1994, Factoring in the UK: A Report and Guide to the Factoring Industry, DTI / HMSO: London.

Christie, G.N., and A.E. Bracuti, 1981, Credit Management, Credit Research Foundation Inc., New York.

Coase, R.A., 1937, “The nature of the firm”, Economica, 4: 386-405.

Colbert, G., and B. Spicer, 1995, "A Multi-case investigation of a theory of the transfer pricing process”, Accounting Organizations and Society, 20, 6: 423-456.

Dun and Bradstreet Australia Pty. Ltd., 1995, Credit and Financial Analysis in Australia.

Edwards, B., 1990, Credit Management Handbook, $3^{\text {rd }}$ edition, Gower, New York.

Ennew, C.T., and M.R. Binks, 1996, "The Provision of Finance to Small Businesses: Does the Banking Relationship Constrain Performance”, Journal of Small Business Finance, 4, 1: 57-73.

Hutton, B., S. Bellamy, and G. Walters, 1997, "Making Risk Assessment Decisions: A Credit Management Perspective”, RMIT Department of Accountancy, Working Paper No. 37.

Kirkman, P.R.A., 1977, Modern Credit Management: A Study of the Management of Trade Credit under Inflationary Conditions, George Allen \& Unwin, New York.

Klein, B., R. Crawford, and A. Alchian, 1978, "Vertical integration, appropriable rents and the competitive contracting process”, Journal of Law and Economics, 21: 297-326.

Mian, S.L., and C.W. Smith, 1992, “Accounts Receivable Management Policy: Theory and Evidence”, The Journal of Finance, XLVII, 1: 169-200.

Mian, S.L., and C.W. Smith, 1994, "Extending Trade Credit and Financing Receivables", Journal of Applied Corporate Finance, 75-84. 
Miller, C., 1996, "How to Write a Credit Policy”, Technical Paper, Credit Research Foundation.

Pike, R., and N. Cheng, 1996, "Business Trade Credit Management: Experience of Large UK Firms”, University of Bradford Management Centre Working Paper Series, Paper No. 9613.

Pike, R., N. Cheng, and L. Chadwick, 1997, Managing Credit for Competitive Advantage: A Survey of Large UK Companies, Chartered Institute of Management Accountants.

Ratnatunga, J., R. Pike, and G. J. Hooley, 1989, "New Evidence on the Accounting-Marketing Interface”, British Accounting Review, 21, 4: 351-370.

Roberts, P., 1993, “'Last resort' makes a comeback” The Australian Financial Review, Wednesday, April 28.

Scott, L.K., 1981, The Australian Credit Management Manual, Longman Cheshire, Melbourne.

Shareholder, 1997, Top 500 Companies on CD ROM, Ian Huntley Pty Ltd, Sydney.

Simmonds, K., 1986, “The Accounting Assessment of Competitive Position”, European Journal of Marketing, 20, 1: 16-31.

Slater, S.F., and J.C. Narver, 1994, "Market orientation, customer value, and superior performance”, Business Horizons, March/April: 22-28.

Smith, J.K., and C. Schnucker, 1994, “An Empirical Examination of Organizational Structure: The Economics of the Factoring Decision”, Journal of Corporate Finance, 1, 1: 119-138.

Society of Management Accountants of Canada, 1990, Management Accounting Guidelines: Accounts Receivable Management, The Society of Management Accountants of Canada, Toronto.

Sopranzetti, B.J., 1998, “The Economics of Factoring Accounts Receivable”, Journal of Economics and Business, 50: 339-359.

Storey, D.J., 1994, Understanding the Small Business Sector, Routledge: New York.

Summers, B., and N. Wilson, 2000, "Trade Credit Management and the Decision to Use Factoring: An Empirical Study”, Journal of Business Finance and Accounting, 27, 1\&2: 3768.

Tabachnick, B.G., and L.S. Fidell, 2001, Using Multivariate Statistics, Allyn and Bacon, Boston.

Telser, L.G., 1960, "Why should manufacturers want fair trade?”, Journal of Law and Economics, 3: 86-105.

Williamson, O. E., 1975, Markets and Hierarchies; Analysis and Antitrust Implications, Free Press: New York. 
Williamson, O. E., 1985, The Economic Institutions of Capitalism, Free Press: New York.

Wilson, N., and K. Watson, 1995, “Trading Relationships, Credit Management and Corporate Performance: A Survey”, University of Bradford, Research Report.

Wilson, R.M.S., 1986, “Accounting for Marketing Assets”, European Journal of Marketing, 20, 1: $51-74$. 
Table 1. Descriptive statistics: usage of TCM outsourcing

\begin{tabular}{|c|c|c|c|c|c|c|c|c|}
\hline \multirow[b]{2}{*}{ Variable } & \multirow[b]{2}{*}{$n$} & \multirow[b]{2}{*}{ Mean } & \multirow[b]{2}{*}{ S.D. } & \multicolumn{5}{|c|}{$\begin{array}{c}\text { Frequency distribution } \\
\text { (1: used not at all; 5: used very frequently) }\end{array}$} \\
\hline & & & & 1 & 2 & 3 & 4 & 5 \\
\hline Credit risk assessment & 65 & 2.49 & 1.53 & 27 & 8 & 12 & 7 & 11 \\
\hline $\begin{array}{l}\text { Credit collection } \\
\text { of overdue accounts }\end{array}$ & 61 & 2.21 & 1.29 & 26 & 12 & 10 & 10 & 3 \\
\hline $\begin{array}{l}\text { Credit granting } \\
\text { decisions }\end{array}$ & 61 & 1.98 & 1.38 & 37 & 5 & 6 & 9 & 4 \\
\hline Credit collection & 62 & 1.89 & 1.24 & 36 & 9 & 8 & 6 & 3 \\
\hline Credit insurance & 61 & 1.59 & 1.23 & 46 & 6 & 2 & 2 & 5 \\
\hline $\begin{array}{l}\text { Financing of accounts } \\
\text { receivable }\end{array}$ & 59 & 1.27 & 0.81 & 51 & 4 & 1 & 2 & 1 \\
\hline
\end{tabular}

Usage of TCM outsourcing measured on an end-anchored 5-point Likert scale. "1" connotes practice used "not at all", and " 5 " connotes practice used "very frequently". 
TABLE 2. Matrix of Spearman's rho correlation coefficients for outsourcing of the six TCM practices

\begin{tabular}{ccccc}
$\begin{array}{c}\text { Credit risk } \\
\text { assessment }\end{array}$ & $\begin{array}{c}\text { Credit collection } \\
\text { of overdue accounts }\end{array}$ & $\begin{array}{c}\text { Credit granting } \\
\text { decisions }\end{array}$ & $\begin{array}{c}\text { Credit } \\
\text { collection }\end{array}$ & $\begin{array}{c}\text { Credit } \\
\text { insurance }\end{array}$ \\
\hline
\end{tabular}

\begin{tabular}{|c|c|c|c|c|c|}
\hline $\begin{array}{l}\text { Credit collection } \\
\text { of overdue accounts }\end{array}$ & $0.57 *$ & & & & \\
\hline $\begin{array}{l}\text { Credit granting } \\
\text { decisions }\end{array}$ & $0.68 *$ & $0.58^{*}$ & & & \\
\hline Credit collection & $0.65 *$ & $0.73 *$ & $0.72 *$ & & \\
\hline Credit insurance & $0.33 * *$ & $0.52 *$ & $0.37 *$ & $0.27 * *$ & \\
\hline $\begin{array}{l}\text { Financing of } \\
\text { accounts receivable }\end{array}$ & $0.47 *$ & $0.47 *$ & $0.52 *$ & $0.56^{*}$ & $0.69 *$ \\
\hline
\end{tabular}

*: Correlation is significant at the .01 level (2-tailed)

**: Correlation is significant at the .05 level (2-tailed)

Table 3. Factor analysis of outsourcing of the 6 TCM practices

\begin{tabular}{lcc}
\hline \multicolumn{1}{c}{ Factoring practice } & Factor 1 & Factor 2 \\
\hline Credit collection & 0.891 & 0.195 \\
Credit granting decisions & 0.855 & 0.192 \\
Credit risk assessment & 0.825 & 0.161 \\
Credit collection of overdue accounts & 0.712 & 0.419 \\
Credit insurance & 0.009 & 0.959 \\
Financing of accounts receivable & 0.423 & 0.784 \\
Eigenvalues & 3.67 & 1.04 \\
\% of variance explained & $61.16 \%$ & $17.37 \%$ \\
\hline
\end{tabular}

The principal component method of extraction with varimax rotation generated the reported loadings. 
Table 4. Spearman's rho correlations of TCM outsourcing with company size

\begin{tabular}{|c|c|c|c|c|c|c|}
\hline & $\begin{array}{c}\text { Credit risk } \\
\text { assessment }\end{array}$ & $\begin{array}{c}\text { Credit } \\
\text { granting } \\
\text { decision }\end{array}$ & $\begin{array}{c}\text { Credit } \\
\text { collection }\end{array}$ & $\begin{array}{c}\text { Credit } \\
\text { collection of } \\
\text { overdue } \\
\text { accounts }\end{array}$ & $\begin{array}{c}\text { Credit } \\
\text { insurance }\end{array}$ & $\begin{array}{c}\text { Financing } \\
\text { of accounts } \\
\text { receivable }\end{array}$ \\
\hline $\begin{array}{c}\text { Market } \\
\text { Capitalization }\end{array}$ & -0.195 & -0.116 & -0.139 & $-0.295^{*}$ & $-0.184^{* *}$ & $-0.210^{* *}$ \\
\hline $\begin{array}{c}\text { Total } \\
\text { Assets }\end{array}$ & -.0 .136 & -0.103 & 0.027 & -0.109 & -0.108 & -0.121 \\
\hline
\end{tabular}

${ }^{*}: p<0.05$ (one tailed)

${ }^{* *}: p<0.1$ (one tailed)

$n$ ranges from 60 to 65 
Table 5. TCM outsourcing mean scores by sales orientation

\begin{tabular}{|c|c|c|c|c|c|c|c|c|}
\hline & \multicolumn{8}{|c|}{ Company modifies standard credit terms to: } \\
\hline & \multicolumn{2}{|c|}{ Win new customers } & \multicolumn{2}{|c|}{$\begin{array}{c}\text { Gain large orders from existing } \\
\text { customers }\end{array}$} & \multicolumn{2}{|c|}{ Keep existing customers } & \multicolumn{2}{|c|}{$\begin{array}{c}\text { Promote slow } \\
\text { moving/declining products }\end{array}$} \\
\hline & $\underline{\text { Yes }}$ & No & Yes & No & $\underline{\text { Yes }}$ & No & Yes & No \\
\hline $\begin{array}{l}\text { Credit risk } \\
\text { assessment } \\
\text { outsourced }\end{array}$ & 2.54 & 2.46 & $2.80 * *$ & 2.23 & 2.62 & 2.41 & $3.10^{*}$ & 2.38 \\
\hline $\begin{array}{l}\text { Credit granting } \\
\text { decisions } \\
\text { outsourced }\end{array}$ & 2.00 & 1.97 & 2.17 & 1.81 & 1.74 & 2.13 & $2.60 *$ & 1.86 \\
\hline $\begin{array}{l}\text { Credit } \\
\text { collection } \\
\text { outsourced } \\
\end{array}$ & 1.95 & 1.85 & $2.14^{* *}$ & 1.67 & 1.70 & 2.00 & 2.11 & 1.85 \\
\hline $\begin{array}{l}\text { Credit } \\
\text { collection of } \\
\text { overdue } \\
\text { accounts }\end{array}$ & $2.50 *$ & 2.05 & $2.60 * *$ & 1.84 & 2.04 & 2.32 & $3.10 * * *$ & 2.04 \\
\hline $\begin{array}{l}\text { Credit insurance } \\
\text { outsourced }\end{array}$ & 1.81 & 1.47 & $1.90 * *$ & 1.29 & 1.36 & 1.72 & $2.40^{* *}$ & 1.43 \\
\hline $\begin{array}{l}\text { Financing of } \\
\text { accounts } \\
\text { receivable }\end{array}$ & 1.25 & 1.28 & 1.43 & 1.13 & 1.05 & 1.39 & 1.12 & 1.29 \\
\hline$n$ & $21-22$ & $39-43$ & $28-30$ & $31-35$ & $22-24$ & $39-41$ & $9-10$ & $51-55$ \\
\hline
\end{tabular}

*: Mann-Whitney $U$ significant at the 0.1 level (1-tailed test)

**:Mann-Whitney $U$ significant at the 0.05 level (1-tailed test)

***: Mann-Whitney $U$ significant at the 0.01 level (1-tailed test) 

Table 6. Means of TCM outsourcing by industry

\begin{tabular}{|c|c|c|c|c|c|c|}
\hline & $\begin{array}{c}\text { Credit risk } \\
\text { assessment }\end{array}$ & $\begin{array}{c}\text { Credit } \\
\text { granting } \\
\text { decision }\end{array}$ & $\begin{array}{c}\text { Credit } \\
\text { collection }\end{array}$ & $\begin{array}{c}\text { Credit } \\
\text { collection } \\
\text { of overdue } \\
\text { accounts }\end{array}$ & $\begin{array}{c}\text { Credit } \\
\text { insurance }\end{array}$ & $\begin{array}{c}\text { Financing of } \\
\text { accounts } \\
\text { receivable }\end{array}$ \\
\hline $\begin{array}{c}\text { Electronic \& } \\
\text { communications } \\
(n=9)\end{array}$ & 2.89 & 2.25 & 2.25 & 2.12 & 1.28 & 1.14 \\
\hline $\begin{array}{c}\text { Manufacturing } \\
(n=15)\end{array}$ & 2.73 & 1.86 & 2.00 & 2.28 & 1.33 & 1.00 \\
\hline $\begin{array}{c}\text { Construction } \\
\text { and property } \\
(n=7)\end{array}$ & 2.57 & 1.86 & 2.00 & 2.14 & 1.86 & 1.86 \\
\hline $\begin{array}{c}\text { Extraction \& } \\
\text { exploration } \\
(n=13)\end{array}$ & 1.38 & 1.23 & 1.07 & 1.31 & 1.31 & 1.08 \\
\hline $\begin{array}{c}\text { Kruskall Wallis } \\
H\end{array}$ & $9.01^{*}$ & 4.63 & $8.85^{*}$ & $7.71^{*}$ & 1.00 & $4.83^{* *}$ \\
\hline
\end{tabular}

$*: p<0.05$ (Kruskall Wallis $H$ statistic one tailed)

**: $p<0.10$ (Kruskall Wallis $H$ statistic one tailed) 